\title{
APLIKASI DOE UNTUK MENENTUKAN SETTING PARAMETER OPTIMUM PADA PROSES PEMBUATAN PRODUK ROLL
}

\author{
Paulus Wisnu Anggoro ${ }^{1}$ \\ ${ }^{1}$ Staf Pengajar Program Studi Teknik Industri Fakultas Teknologi Industri \\ Universitas Atma Jaya Yogyakarta INDONESIA. \\ Email: p_wisnu@mail.uajy.ac.id
}

\begin{abstract}
Problem faced by Atmaja Jaya Industry, Klaten is how to produce high quality products with a minimal amount of defective products. Therefore, this study will look at factor that affect the quality of roll 6" TL in order to obtain the best level setting in the production process. This study uses experimental design with the Taguchi method. Factors to be tested in this study is long making liquid metal (factor A), the old foundry (factor B), and total time of casting (factor C). Each factor has three levels so that the use of orthogonal array $\mathrm{L}_{9} 3^{4}$. From the result of pooling up mean, the best level combination of factors that affect the quality of roll 6"TL is the length of manufacture of liquid metal which set at 100 minutes, the old foundry is set at 5 seconds and the total time of casting that set in 14 minutes. While the result of pooling up SN ratio for the best level combination of factors that affect the quality of production process variants roll 6"TL which the length of the manufacture of liquid is set at 100 minutes and total time of casting that are set in 14 minutes.
\end{abstract}

Keywords: Taguchi Method, Orthogonal Array, Roll 6" TL, Product defect

\section{Pendahuluan}

\section{a. Latar Belakang}

Industri cor logam yang memproduksi komponen mesin memiliki peranan yang cukup vital di bidang industri. Hal ini terjadi karena sebagian komponen mesin yang digunakan dapat dibuat di Indonesia. Berkembangnya industri cor logam dengan proses sand casting yang ada menimbulkan persaingan ketat antar pelaku produksi. Industri cor logam berkembang pesat di Kabupaten Klaten tepatnya Desa Batur, Kecamatan Ceper.

Penelitian ini dilakukan di PT. Atmaja Jaya yang bergerak di industri cor logam yang berlokasi di Desa Batur, Ceper, Klaten. Perusahaan ini bukan termasuk home industry karena tidak dikelola oleh perseorangan saja. Produk yang dibuat adalah produk recycle yang artinya apabila terjadi cacat dalam produk akhir maka dapat diolah kembali dengan cara dijadikan bahan baku utama berupa gram.

Tahap penelitian awal yang dilakukan peneliti adalah proses pengambilan data awal berupa jumlah produksi dan jumlah produk cacat. Data awal yang didapatkan dapat memberikan kesimpulan bahwa perusahaan dapat mengalami kemungkinan kerugian yang besar. Dalam satu semester (6 bulan) PT. Atmaja Jaya, Klaten dapat memproduksi produk roll sejumlah 87.026 unit produk setengah jadi. Jumlah tersebut dapat diolah menjadi produk roll jadi dan dapat langsung dikirimkan kepada konsumen. Angka produksi tersebut adalah perkiraan permintaan pasar dan pendapatan pihak perusahaan. Menurut perhitungan perkiraan pendapatan, perusahaan memiliki perkiraan pendapatan sejumlah Rp 1.079.018.000,00 per 6 (enam) bulan dengan mengabaikan kerugian terhadap jumlah produksi cacat. Perhitungan jumlah cacat yang dialami perusahaan selama satu semester (6 bulan) berjumlah 6.686 unit. Perhitungan perkiraan kerugian yang dialami perusahaan sebesar Rp 83.670.000,00 per semester. Angka perkiraan kerugiaan yang sebesar itu akan 
dialami perusahaan dan tidak menutup kemungkinan akan menjadi lebih besar pada semester-semester berikutnya.

Penelitian awal juga bertujuan untuk membantu peneliti memilih produk roll mana yang akan diteliti. Peneliti menetapkan bahwa produk roll setengah jadi tipe 6"TL adalah produk yang akan diteliti. Peneliti melihat angka perkiraan kerugian pada produk roll setengah jadi tipe 6"TL adalah yang terbesar. Perusahaan mengalami kerugiaan sebesar Rp 29.656.000,00 per semester karena produk roll setengah jadi tipe 6"TL memiliki jumlah cacat yang terbanyak. Selain itu juga bertujuan untuk mengidentifikasi permasalah yang ada. Akar permasalahan dari tingginya jumlah cacat produk terjadi karena proses produksi yang salah. Penilitian ini akan menganalisis faktor pada proses produksi yang berpengaruh terhadap kualitas hasil produk roll 6"TL. Penilitian ini juga bertujuan menganalisis pada level berapa yang optimal pada setiap faktor yang dianggap berpengaruh sehingga dapat mengurangi jumlah produk cacat yang terjadi.

\section{b. Perumusan Masalah}

Berdasarkan latarbelakang permasalahan maka permasalahan yang akan dibahas dalam penelitian ini adalah bagaimana meminimalkan jumlah produk cacat dan meminimalkan jumlah kerugian perusahaan karena produk cacat?

\section{c. Tujuan Penelitian}

Tujuan penelitian ini adalah:

1. Mengidentifikasi faktor-faktor yang mempengaruhi kualitas hasil produksi pada proses produksi pembuatan roll setengah jadi tipe 6"TL.

2. Menentukan seting parameter yang tepat agar mendapatkan kualitas roll yang optimal.

\section{d. Batasan Masalah}

Batasan masalah pada penelitian yang akan dilakukan adalah sebagai berikut:

1. Produk yang menjadi objek penelitian adalah roll 6"TL.

2. Metode penelitian yang dipakai adalah perancangan eksperimen dengan metode Taguchi.

3. Tidak membahas uncontrolled factor seperti cuaca lingkungan kerja.

4. Penelitian dilakukan hanya sampai pada tahap pembongkaran cetakan atau produk setengah jadi.

\section{e. Metodologi Penelitian}

Metodologi penelitian ini digambarkan berupa flowchart berikut ini: 

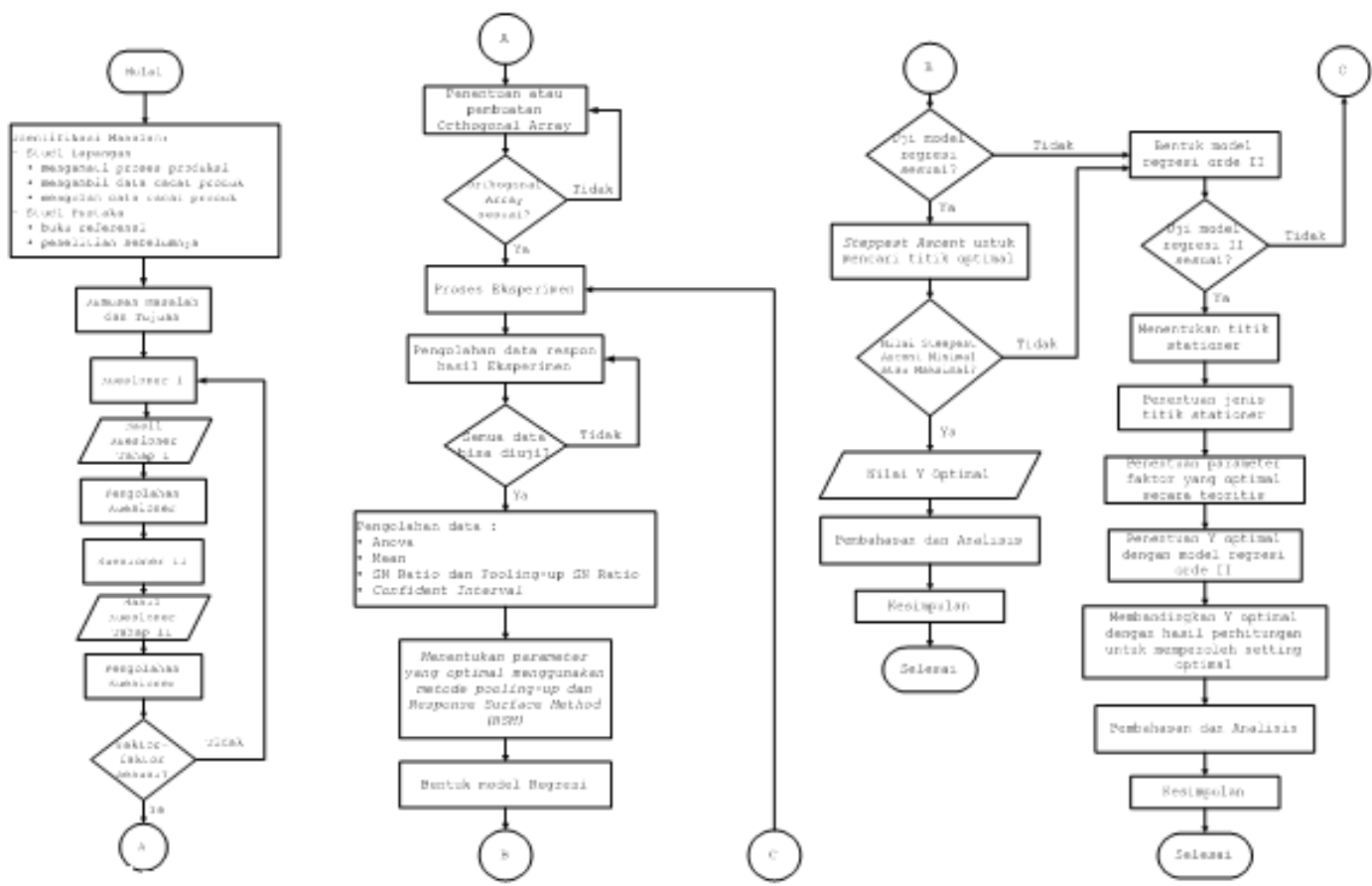

Gambar 1. Diagram Alir Metodologi Penelitian

\section{Landasan Teori}

\section{a. Metode Taguchi}

Metode Taguchi adalah suatu metode dimana kualitas diukur berdasarkan deviasi dari karakteristik terhadap nilai targetnya ${ }^{[7]}$. Definisi kualitas menurut Taguchi adalah "The quality of a product is the (minimum) loss imparted by the product to society from the time the product is shipped", yang berarti bahwa kualitas suatu produk adalah kerugian minimum yang diberikan oleh suatu produk kepada masyarakat atau konsumen sejak mulai produk tersebut siap untuk dikirim ke konsumen. Metode Taguchi merupakan teknik untuk merekayasa atau memperbaiki produktivitas selama tahap pengembangan, supaya produkproduk yang berkualitas dapat dihasilkan dengan cepat dan dengan biaya yang rendah. Selain itu Taguchi menyatakan dua pendekatan pengendalian kualitas yaitu on line quality control dan off line quality control ${ }^{[2]}$.

On line quality control adalah kegiatan pengendalian kualitas yang bersifat reaktif atau tindakan pengendalian kualitas yang dilakukan setelah kegiatan produksi berjalan. Sedangkan Off line quality control (product design) lebih bersifat preventif yang artinya adalah pengendalian kualitas yang dilakukan sebelum proses produksi berjalan.

\section{b. Orthogonal Array}

Orthogonal array digunakan untuk mendesain percobaan yang efisien dan menganalisis data percobaan serta meminimalkan jumlah eksperimen yang dapat memberi informasi sebanyak mungkin semua faktor yang berpengaruh.

Penelitian ini menggunakan $\mathrm{L}_{9}\left(3^{4}\right)$ hal tersebut karena berdasarkan hasil kuesioner didapatkan 3 faktor yang berpengaruh serta ada 3 level yang akan diuji. Eksperimen dipilih sejumlah 9 kali observasi karena dalam tabel standar orthogonal array yang mendekati 3 faktor dengan 3 level adalah kolom $\mathrm{L}_{9}\left(3^{4}\right)$. Pemilihan orthogonal array harus memenuhi pertidaksamaan $^{[2]}$ :

$$
\mathrm{V}_{\mathrm{OA}} \geq \mathrm{V}_{\mathrm{T}}
$$


yaitu jumlah eksperimen $-1 \geq$ jumlah total d.o.f untuk semua faktor dan interaksinya, dengan:

$\mathrm{V}_{\mathrm{OA}}$ : jumlah percobaan -1

$\mathrm{V}_{\mathrm{T}} \quad$ : jumlah total d.o.f dari seluruh faktor

Berikut tabel standar untuk orthogonal array yang ditabulasi oleh Taguchi ${ }^{[2]}$ :

Tabel 1. Standar Orthogonal Array

\begin{tabular}{|c|c|c|c|c|}
\hline 2 Level & 3 Level & 4 Level & 5 Level & Mixed-Level \\
\hline $\mathrm{L}_{4}\left(2^{3}\right)$ & $\mathrm{L}_{9}\left(3^{4}\right)$ & $\mathrm{L}_{16}\left(4^{5}\right)$ & $\mathrm{L}_{25}\left(5^{6}\right)$ & $\mathrm{L}_{18}\left(2^{1} \times 3^{7}\right)$ \\
\hline $\mathrm{L}_{8}\left(2^{7}\right)$ & $\mathrm{L}_{27}\left(3^{13}\right)$ & $\mathrm{L}_{64}\left(4^{21}\right)$ & - & $\mathrm{L}_{32}\left(2^{1} \times 4^{9}\right)$ \\
\hline $\mathrm{L}_{12}\left(2^{11}\right)$ & $\mathrm{L}_{81}\left(3^{40}\right)$ & - & - & $\mathrm{L}_{36}\left(2^{11} \times 3^{12}\right)$ \\
\hline $\mathrm{L}_{16}\left(2^{15}\right)$ & - & - & - & $\mathrm{L}_{36}\left(2^{3} \times 3^{13}\right)$ \\
\hline $\mathrm{L}_{32}\left(2^{31}\right)$ & $\bullet$ & $\bullet$ & $\bullet$ & $\mathrm{L}_{54}\left(2^{1} \times 3^{25}\right)$ \\
\hline $\mathrm{L}_{64}\left(2^{63}\right)$ & $\bullet$ & $\bullet$ & $\bullet$ & $\mathrm{L}_{50}\left(2^{1} \times 5^{11}\right)$ \\
\hline
\end{tabular}

\section{c. Pengujian Distribusi Normal}

Uji kenormalan data ini untuk mengetahui bahwa populasi yang diselidiki berdistribusi normal. Menguji kenormalan data dengan plot kenormalan data (normal probability plot), Jika distribusi tersebut menyebar normal, maka plot data sample berada di sekitar garis lupus. Jika asumsi ini tidak dipenuhi, artinya ternyata populasi yang diselidiki tidak berdistribusi normal, maka kesimpulan dari ANOVA tidak berlaku. Karenanya sebelum teori lebih lanjut digunakan dan kesimpulan diambil berdasarkan teori dimana asumsi normalitas dipakai, terlebih dahulu perlu diketahui apakah data sudah berdistribusi normal atau belum.

\section{d. Pengujian Homogenitas Data}

Uji homogenitas data dilakukan dengan tujuan untuk mengetahui apakah sampel tersebut ditarik dari populasi yang berdistribusi seragam.

\section{e. Pengujian T-test}

Uji hipotesis ini dilakukan untuk membandingkan rata-rata suatu populasi. Salah satu metodenya adalah uji t. uji t dilakukan apabila jumlah sampel tidak cukup besar, dalam hal ini jumlah sampel kurang dari $30(n<30)$ dan standar deviasi $(\delta)$ populasi tidak diketahui. Penelitian ini menggunakan banyaknya sampel adalah tiga (R1, R2, dan R3) dengan jumlah ukuran setiap sampel adalah delapan.

\section{f. ANOVA}

Analysis of Variance (ANOVA) merupakan alat analisis yang efektif bagi perbandingan populasi yang simultan untuk menentukan apakah populasi-populasi tersebut identik atau berbeda secara signifikan. ANOVA juga merupakan sumber penting untuk mengevaluasi data yang ada dan sebagai alat yang digunakan bersama dengan suatu perancangan eksperimen. Untuk penelitian ini, perhitungan Anova dilakukan dengan menggunakan bantuan program software. ANOVA dapat dilakukan dalam beberapa langkah berikut : 


\section{i. Menghitung sum of squares}

Perhitungan sum of squares dapat dilakukan dengan persamaan berikut ${ }^{[2]}$ :

a. Total sum of squares

$$
S S_{T}=\sum_{i=1}^{a} \sum_{j=1}^{b} \sum_{k=1}^{c} \sum_{l=1}^{n} X_{i j k l}^{2}-\frac{T^{2}}{a b c n}
$$

dimana

$$
\mathrm{T}=\sum_{\mathrm{i}} \sum_{\mathrm{j}} \sum_{\mathrm{k}} \sum_{\mathrm{l}} \mathrm{X}_{\mathrm{ijk} 1}
$$

dengan : $a=$ jumlah faktor $A$

$\mathrm{b}=$ jumlah faktor $\mathrm{B}$

$\mathrm{c}=$ jumlah faktor $\mathrm{C}$

$\mathrm{n}=$ jumlah replikasi

b. Sum of squares for main effects (treatment sum of squares)

$$
\begin{aligned}
& S S_{A}=\frac{1}{b c n} \sum_{i=1}^{a} X_{i}^{2}-\frac{T^{2}}{a b c n} \\
& S S_{B}=\frac{1}{a c n} \sum_{j=1}^{b} X_{j}^{2}-\frac{T^{2}}{a b c n} \\
& S S_{C}=\frac{1}{a b n} \sum_{k=1}^{c} X_{k}^{2}-\frac{T^{2}}{a b c n}
\end{aligned}
$$

c. The two-factors interaction sum of squares

$$
\begin{aligned}
S S_{A B} & =\frac{1}{c n} \sum_{i=1}^{a} \sum_{j=1}^{b} X_{i j}^{2}-\frac{T^{2}}{a b c n}-S S_{A}-S S_{B} \\
& =S S_{\text {Subtotal } A B)}-S S_{A}-S S_{B} \\
S S_{A C} & =\frac{1}{b n} \sum_{i=1}^{a} \sum_{k=1}^{c} X_{i k}^{2}-\frac{T^{2}}{a b c n}-S S_{A}-S S_{C} \\
& =S S_{\text {Subtotal } A C)}-S S_{A}-S S_{C} \\
S S_{B C} & =\frac{1}{a n} \sum_{j=1}^{b} \sum_{k=1}^{c} X_{j k}^{2}-\frac{T^{2}}{a b c n}-S S_{B}-S S_{C} \\
& =S S_{\text {Subtotalk } B C)}-S S_{B}-S S_{C}
\end{aligned}
$$

d. The three-factors interaction sum of squares

$$
\begin{aligned}
S S_{A B C} & =\frac{1}{n} \sum_{i=1}^{a} \sum_{j=1}^{b} \sum_{k=1}^{c} X_{j k}^{2}-\frac{T^{2}}{a b c n}-S S_{A}-S S_{B}-S S_{C}-S S_{A B}-S S_{A C}-S S_{B C} \\
& =S S_{\text {Subtotal } A B C)}-S S_{A}-S S_{B}-S S_{C}-S S_{A B}-S S_{A C}-S S_{B C}
\end{aligned}
$$

e. The error sum of squares

$$
\mathrm{SS}_{E}=\mathrm{SS}_{\mathrm{T}}-\left(\mathrm{SS}_{\text {Treatments }}+\mathrm{SS}_{\text {Interactions }}\right)
$$

\section{ii. Menentukan degrees of freedom (derajat kebebasan)}

Perhitungan derajat kebebasan (degrees of freedom) dilakukan untuk menghitung jumlah minimum percobaan yang harus dilakukan untuk menyelidiki faktor-faktor yang diamati ${ }^{[2]}$. Derajat kebebasan untuk faktor dan level faktor dihitung dengan rumus :

$$
\mathrm{v}_{T}=\text { jumlah level }-1
$$

Derajat kebebasan untuk orthogonal arrays adalah:

$$
\mathrm{v}_{O A}=\text { jumlah eksperimen }-1
$$


Misalkan $\mathrm{n}_{\mathrm{A}}$ dan $\mathrm{n}_{\mathrm{B}}$ adalah jumlah level untuk faktor $\mathrm{A}$ dan faktor $\mathrm{B}$ maka ${ }^{[2]}$ :

$$
\begin{aligned}
\mathrm{v}_{\mathrm{A}}=\mathrm{n}_{\mathrm{A}}-1 \\
\mathrm{v}_{\mathrm{B}}=\mathrm{n}_{\mathrm{B}}-1 \\
\mathrm{v}_{\mathrm{A}} \times \mathrm{v}_{\mathrm{B}}=\left(\mathrm{n}_{\mathrm{A}}-1\right)\left(\mathrm{n}_{\mathrm{B}}-1\right) \\
\mathrm{v}_{\mathrm{T}}=\left(\mathrm{n}_{\mathrm{A}}-1\right)+\left(\mathrm{n}_{\mathrm{B}}-1\right)+\left(\mathrm{n}_{\mathrm{A}}-1\right)\left(\mathrm{n}_{\mathrm{B}}-1\right) \\
\text { dengan } \mathrm{v}_{\mathrm{A}} \quad=\text { degree of freedom faktor } \mathrm{A} \\
\mathrm{v}_{\mathrm{B}} \quad=\text { degree of freedom faktor } \mathrm{B} \\
\mathrm{v}_{\mathrm{A}} \times \mathrm{v}_{\mathrm{B}}=\text { degree of freedom untuk interaksi faktor } \mathrm{A} \times \mathrm{B} \\
\mathrm{v}_{\mathrm{T}}=\text { degree of freedom total }
\end{aligned}
$$

\section{iii. Menghitung Mean Squares (MS)}

Mean squares atau rata-rata jumlah kuadrat diperoleh dengan cara membagi jumlah kuadrat dengan derajat kebebasan yang sesuai. Perhitungan mean squares dapat dilakukan dengan persamaan berikut ${ }^{[2]}$ :

$$
\begin{aligned}
& M S_{\text {Treatments }}=\frac{S S_{\text {Treatments }}}{d f_{\text {Treatments }}} \\
& M S_{\text {Interactions }}=\frac{S S_{\text {Interactions }}}{d f_{\text {Interactions }}} \\
& M S_{\text {Error }}=\frac{S S_{E}}{d f_{\text {Error }}}
\end{aligned}
$$

\section{iv. Menghitung F ratio}

Uji ini dilakukan untuk melihat apakah ada perbedaan-perbedaan yang secara signifikan pada faktor-faktor dan interaksi antar faktor. Uji ini dilakukan dengan cara membandingkan variasi yang disebabkan masing-masing faktor dengan variasi error. Variasi error adalah variasi setiap individu dalam pengmatan yang timbul karena faktorfaktor (luar) yang tidak dapat dikendalikan. Misal untuk faktor A, maka uji F ratio adalah sebagai berikut ${ }^{[2]}$ :

$$
F_{A}=\frac{M S_{A}}{M S_{E}}
$$

dengan $\mathrm{MS}_{\mathrm{A}}$ = rata-rata jumlah kuadrat faktor $\mathrm{A}$

$\mathrm{MS}_{\mathrm{E}}=$ rata-rata jumlah kuadrat error

\section{v. Mencari nilai kritis $\mathbf{F}$}

Hasil uji $\mathrm{F}$ ratio tersebut dibandingkan dengan nilai $\mathrm{F}$ dari tabel pada harga $\alpha$ tertentu. Nilai kritis $\mathrm{F}\left(\mathrm{F}_{\text {critical }}\right)$ ditentukan dari tabel distribusi $\mathrm{F}$, tergantung pada derajat kebebasan pada numerator ( $\mathrm{df}{ }_{\text {Numerator }}$ ), derajat kebebasan pada deminator ( $\mathrm{df}$ Deminator ), dan level of significance yang dipilih $(\alpha)$.

$$
\mathrm{F}_{\text {critical }}=\mathrm{F}\left(\left(\mathrm{df}_{\text {Numerator }}\right),\left(\mathrm{df}_{\text {Deminator }}\right), \alpha\right)
$$

dengan $\mathrm{df}_{\text {Numerator }}=$ derajat kebebasan untuk faktor, $\mathrm{df}_{\text {Deminator }}=$ derajat kebebasan untuk error

$\alpha=$ tingkat kesalahan (semakin kecil nilai $\alpha$ berarti semakin mengurangi risiko salah)

Nilai $F_{\text {critical }}$ ini dibandingkan dengan nilai $F_{\text {ratio }}$ untuk menentukan apakah variansi data yang signifikan atau tidak, maka: 


$$
\begin{aligned}
& \mathrm{F}_{\text {ratio }}>\mathrm{F}_{\text {critical }} \rightarrow \text { significant } \\
& \mathrm{F}_{\text {ratio }}<\mathrm{F}_{\text {critical }} \rightarrow \text { not significant }
\end{aligned}
$$

\section{g. Persen Kontribusi}

Persen kontribusi merupakan porsi masing-masing faktor dan atau interaksi faktor yang signifikan terhadap total varian yang diamati. Persen kontribusi ini merupakan fungsi dari sum of squares dari masing-masing faktor signifikan yang merupakan indikasi kekuatan sebuah faktor dan atau interaksi faktor. Rumus perhitungan persen kontribusi ${ }^{[2]}$ :

$$
\begin{aligned}
& \mathrm{SS}_{\mathrm{A}}^{\prime}=\mathrm{SS}_{\mathrm{A}}-\left(\mathrm{V}_{\mathrm{e}} \times \mathrm{v}_{\mathrm{A}}\right) \\
& \mathrm{P}=\frac{S S_{A}^{\prime}}{S S_{T}} \times 100 \%
\end{aligned}
$$

dengan $\mathrm{SS}_{\mathrm{A}}=$ jumlah kuadrat murni untuk faktor $\mathrm{A}$

$$
\begin{aligned}
\mathrm{SS}_{\mathrm{A}} & =\text { sum of squares faktor } \mathrm{A} \\
\mathrm{V}_{\mathrm{e}} & =\text { mean squares error } \\
\mathrm{V}_{\mathrm{A}} & =\text { derajat kebebasan faktor } \mathrm{A} \\
\mathrm{SS}_{\mathrm{T}} & =\text { sum of } \text { squares total } \\
\mathrm{P} & =\text { persen kontribusi }
\end{aligned}
$$

Apabila persen kontribusi kurang dari $15 \%$, dapat diasumsikan bahwa tidak ada faktor-faktor penting yang dihilangkan dari eksperimen. Apabila persen kontribusi lebih besar dari $50 \%$, terdapat beberapa faktor penting harus dihilangkan, kondisi tidak terkontrol dengan tepat, atau error pengukuran terlalu besar. Persen kontribusi error merupakan suatu ukuran seberapa banyak pekerjaan yang tersisa untuk dilakukan atau seberapa banyak kesempatan yang masih ada. Apabila nilai persen kontribusi error ini rendah dan banyak faktor yang dipertimbangkan dalam eksperimen, maka kesempatan untuk perbaikan lebih lanjut tidak terlalu besar. Sebaliknya apabila nilai persen kontribusi error tinggi, maka terdapat kesempatan untuk perbaikan lebih lanjut yang besar dan proses produksi lebih banyak akan merugikan.

\section{h. Signal to Noise Ratio}

Signal adalah nilai rata-rata dari karakteristik dan menampilkan komponen yang diinginkan, yang mendekati nilai target yang telah ditentukan. Sedangkan noise adalah komponen yang tidak diinginkan dan diukur melalui variabilitas karakteristik output. Signal to ratio ( $\mathrm{S} / \mathrm{N}$ ratio) ini merupakan suatu nilai yang menunjukkan seberapa besar pengaruh faktor terkendali terhadap kualitas produk yang dihasilkan dan memperhitungkan variasi produk yang dihasilkan serta seberapa dekat produk tersebut dengan target yang telah ditentukan. S/N ratio digunakan untuk memilih faktor-faktor yang memiliki kontribusi pada pengurangan variasi suatu faktor.

Rumus perhitungan $\mathrm{S} / \mathrm{N}$ ratio yang digunakan,yaitu Nominal is The Best. Nilai yang dituju adalah nilai nominal tertentu yang didekati dari dua arah. Semakin mendekati nilai nominal kualitasnya semakin baik. Fungsi ini formulasinya sebagai berikut ${ }^{[2]}$ :

$$
\begin{aligned}
\eta & =10 \log _{10}\left[\frac{\mu^{2}}{\sigma^{2}}\right] \\
\mu & =\frac{1}{n} \sum_{i=i}^{n} y_{i} \\
\sigma^{2} & =\frac{1}{n} \sum\left(y_{i}+\mu\right)^{2}
\end{aligned}
$$




$$
\begin{aligned}
& \text { dengan } \bar{y}=\text { rata-rata pengamatan } \\
& \mathrm{s}^{2} \quad=\text { besarnya varian } \\
& \mathrm{y}_{\mathrm{i}} \quad=\text { pengamatan perulangan ke- } \mathrm{i} \\
& \mathrm{n} \quad=\text { banyak perulangan }
\end{aligned}
$$

\section{i. Strategi Pooling Up}

Strategi pooling up dirancang oleh Taguchi untuk mengestimasi varian error pada analisis varian sehingga estimasi yang dihasilkan akan lebih baik. Strategi ini akan mengakumulasi beberapa varians error dari beberapa faktor yang kurang berarti. Strategi ini menguji $\mathrm{F}$ efek kolom terkecil terhadap yang lebih besar berikutnya untuk melihat kesignifikannya. Dalam hal ini jika tidak ada rasio - F signifikan yang muncul maka kedua efek tersebut dipooling untuk menguji kolom yang lebih besar berikutya sampai dengan rasio $\mathrm{F}$ yang signifikan muncul. Atau dengan kata lain pooling up dilakukan jika pengaruh semua faktor yang diteliti tidak ada yang signifikan. Ini terjadi jika varian kesalahan yang mewakili kesalahan dalam percobaan mempunyai derajat kebebasan relatif lebih kecil atau nol. Oleh karena itu pengaruh faktor yang mempunyai jumlah kuadrat yang paling kecil berikutnya digabungkan dengan jumlah kuadrat kesalahan demikian seterusnya hingga diperoleh yang signifikan. Makin besar harga rasio - F, makin signifikan sumber tersebut.

Dari faktor yang tersisa tersebut akan kembali dilakukan F-test sampai diperoleh hasil pooled setengah dari nilai derajat kebebasan orthogonal array. Tujuannya untuk menghindari estimasi yang berlebihan, selain itu semakin besar nilai degree of freedom dari error sum of squares maka estimasi error sum of squares juga lebih baik ${ }^{[2]}$.

Strategi pooling up cenderung memaksimasi jumlah kolom yang dipertimbangkan signifikan. Dengan keputusan signifikan faktor - faktor tersebut akan digunakan dalam putaran percobaan selanjutnya atau dalam desain produk atau proses. Dengan demikian kecenderungan melakukan kesalahan $\alpha$ (kesalahan tipe I) akan membesar yaitu pertimbangan bahwa faktor menyebabkan perbaikan padahal tidak. Namun keadaan ini lebih baik dari pada melakukan kesalahan $\beta$ (kesalahan tipe II) yaitu pertimbangan bahwa faktor tidak menyebabkan perbaikan padahal sebenarnya menyebabkan perbaikan, rumusnya ${ }^{[2]}$ :

$$
\begin{aligned}
& \mathrm{S}(\text { Pooled } \mathrm{e})=\mathrm{Se}+\mathrm{SD} \\
& \mathrm{V}(\text { Pooled } \mathrm{e})=\mathrm{ve}+\mathrm{vD} \\
& \mathrm{M}(\text { Pooled } \mathrm{e})=\frac{\mathrm{S}(\text { Pooled } \mathrm{e})}{\mathrm{V}(\text { Pooled } \mathrm{e})}
\end{aligned}
$$

\section{j. Selang Kepercayaan}

Sebuah eksperimen setelah dilakukan, sangat penting untuk menentukan rata - rata proses pada sebuah keadaan yang dapat diprediksi. Prediksi ini biasanya sebuah nilai estimasi. Untuk meningkatkan situasi yang diinginkan untuk percobaan bahwa 95\% konfirmasi hasil test harus diantara $\pm \mathrm{x}$ unit dari rata - rata prediksi.

Selang kepercayaan adalah nilai antara minimum dan maksimum dimana rerata seharusnya berada atau terletak pada persentase kepercayaan tersebut. Berikut rumus yang $\operatorname{digunakan}^{[2]}$ :

$$
\begin{aligned}
& \mathrm{CI}=\sqrt{\mathrm{F}_{\alpha, \mathrm{v} 1, \mathrm{v} 2} \times \mathrm{V}_{\mathrm{e}} \times\left[\frac{1}{\mathrm{n}}\right]} \\
& \mu_{\mathrm{A}_{\mathrm{k}}}=\mathrm{A}_{\mathrm{k}} \pm \mathrm{CI} \\
& \mathrm{A}_{\mathrm{k}}-\mathrm{CI} \leq \mu_{\mathrm{A}_{\mathrm{k}}} \leq \mathrm{A}_{\mathrm{k}}+\mathrm{CI}
\end{aligned}
$$




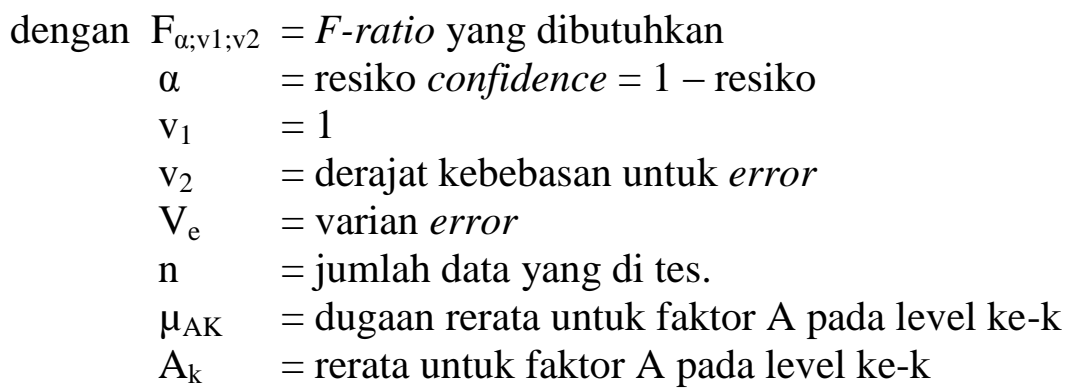

\section{k. Analisis Regresi}

Model regresi memiliki variabel respon (y) dan variabel prediktor (x). Variabel respon adalah variabel yang dipengaruhi oleh variabel prediktor. Variabel respon sering dikenal sebagai variabel independen karena peneliti tidak bisa bebas mengendalikannya. Kemudian variabel prediktor digunakan untuk memprediksi nilai variabel respon dan sering disebut variabel dependen karena peneliti bebas mengendalikannya. Kedua variabel dihubungkan dalam bentuk persamaan matematika. Secara umum, bentuk persamaan regresi dinyatakan sebagai berikut ${ }^{[8]}$ : dengan

$$
\mathrm{Y}=\beta_{0}+\beta_{1} \mathrm{X}_{1}+\beta_{2} \mathrm{x}_{2}+\ldots+\beta_{\mathrm{k}} \mathrm{x}_{\mathrm{k}}+\varepsilon
$$

$\mathrm{y}=$ variabel respon

$\beta_{\mathrm{i}}=$ koefisien regresi, $(\mathrm{i}=0,1,2,3,4)$

$\mathrm{x}_{\mathrm{i}}=$ variabel independen $(\mathrm{i}=1,2,3,4)$

$\mathrm{x}_{1}=$ faktor $\mathrm{A}$

$\mathrm{x}_{2}=$ faktor $\mathrm{B}$

$\mathrm{x}_{3}=$ faktor $\mathrm{C}$

$\mathrm{x}_{4}=$ faktor $\mathrm{D}$

\section{l. Response Surface Methodology (RSM)}

Response surface methodhology (RSM) adalah sekumpulan metode matematika dan teknik-teknik statistik yang bertujuan membuat model dan melakukan analisis mengenai respon yang dipengaruhi oleh beberapa variabel ${ }^{[5]}$. Peneliti menggunakan RSM sebagai upaya mencari fungsi yang tepat untuk memprediksi respons. Tahap pertama dalam RSM adalah mencari fungsi hubungan antara variabel respons dengan variabel independen yang tepat. Dalam permasalahan RSM, peneliti sering tidak mengetahui hubungan antara variabel respon dan variabel independen. Untuk memodelkannya, perlu memeriksa apakah model antarvariabel adalah model linear (model orde satu atau model polinominal). Apabila dalam sistem terdapat pola tidak linear, tentu model yang tepat adalah model polinomial orde tinggi ${ }^{[8]}$.

\section{Model RSM:}

$$
\mathrm{Y}=\beta_{0}+\beta_{1} \mathrm{x}_{1}+\beta_{2} \mathrm{x}_{2}+\beta_{11} \mathrm{x}_{1}{ }^{2}+\beta_{12} \mathrm{x}_{1} \mathrm{x}_{2}+\beta_{22} \mathrm{x}_{2}{ }^{2}+\ldots+\varepsilon
$$

Model RSM orde satu:

$$
Y=\beta_{0}+\beta_{1} x_{1}+\beta_{2} x_{2}+\ldots+\beta_{k} x_{k}+\varepsilon
$$

Model RSM orde dua:

$$
Y=\beta_{0}+\beta_{1} x_{1}+\beta_{2} x_{2}+\beta_{11} x_{1}^{2}+\beta_{22} x_{2}^{2} \ldots++\beta_{12} x_{1} x_{2}+\ldots+\varepsilon
$$


dengan

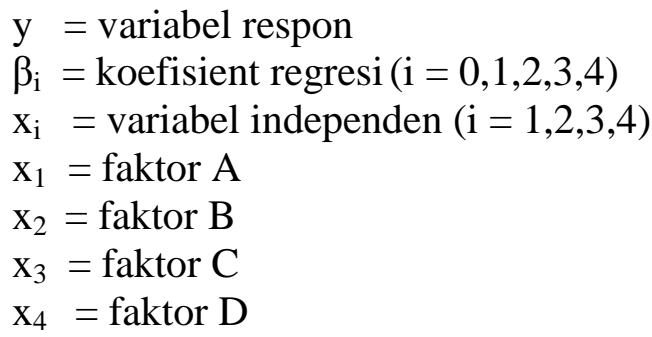

\section{m. Penentuan Titik Stasioner}

Setelah persamaan model orde II yang dibentuk telah sesuai, maka langkah selanjutnya adalah menentukan titik stasioner. Titik stasioner adalah titik dimana respon yang diamati akan maksimal, minimum atau pelana ${ }^{[8]}$.

\section{Data dan Analisis Data}

\subsection{Identifikasi faktor-faktor yang berpengaruh terhadap respon}

Identifikasi faktor-faktor yang dianggap berpengaruh terhadap respon (dalam hal ini adalah hasil pengecoran logam yang optimum) dengan menggunakan kuesioner. Selanjutnya hasil dari kuesioner diolah dengan menggunakan diagram pareto. Hasilnya dapat dilihat pada Tabel 1.

Tabel 1. Faktor dan Nilai Level Yang Digunakan

\begin{tabular}{|c|l|c|c|c|}
\hline \multirow{2}{*}{ No } & \multirow{2}{*}{ Faktor } & \multicolumn{3}{|c|}{ Level Faktor } \\
\cline { 3 - 5 } & & Level 1 & Level 2 & Level 3 \\
\hline 1 & Lama Pembuatan Cairan Logam & 90 menit & 100 menit & 110 menit \\
\hline 2 & Lama Penuangan & 3 detik & 4 detik & 5 detik \\
\hline 3 & Total Waktu Penuangan & 14 menit & 16 menit & 20 menit \\
\hline
\end{tabular}

\subsection{Data Eksperimen}

Eksperimen yang dilakukan kali ini memiliki 3 parameter kontrol dengan 3 level. Maka orthogonal array yang dipilih adalah jenis orthogonal array untuk 3 level parameter. Layout design orthogonal array yang digunakan adalah $\mathrm{L}_{9}\left(3^{4}\right)$ dan menggunakan 9 perlakuan eksperimen dengan 4 replikasi pada tiap perlakuan. Dimana huruf A (lama pembuatan cairan logam), B (lama penuangan), C (total waktu penuangan). Angka-angka 1,2 dan 3 menunjukkan level dari tiap parameter. $R_{1}, R_{2}, R_{3}$, dan $R_{4}$ menunjukkan hasil replikasi respon yang diukur dalam jumlah cacat produksi. Data eksperimen dapat dilihat pada Tabel 2.

Tabel 2. Data Eksperimen

\begin{tabular}{|c|c|c|c|c|c|c|c|}
\hline $\mathbf{E X P}$ & $\mathbf{A}$ & $\mathbf{B}$ & $\mathbf{C}$ & $\mathbf{R}_{\mathbf{1}}$ & $\mathbf{R}_{\mathbf{2}}$ & $\mathbf{R}_{\mathbf{3}}$ & $\mathbf{R}_{\mathbf{4}}$ \\
\hline 1 & 1 & 1 & 1 & 236 & 255 & 212 & 243 \\
\hline 2 & 1 & 2 & 2 & 216 & 232 & 244 & 229 \\
\hline 3 & 1 & 3 & 3 & 262 & 221 & 216 & 232 \\
\hline 4 & 2 & 1 & 2 & 268 & 255 & 281 & 201 \\
\hline 5 & 2 & 2 & 3 & 240 & 264 & 211 & 244 \\
\hline 6 & 2 & 3 & 1 & 104 & 124 & 97 & 102 \\
\hline 7 & 3 & 1 & 3 & 242 & 236 & 232 & 241 \\
\hline 8 & 3 & 2 & 1 & 140 & 172 & 144 & 142 \\
\hline 9 & 3 & 3 & 2 & 235 & 240 & 244 & 239 \\
\hline
\end{tabular}




\subsection{Pengolahan Data}

1. Uji normalitas dan homogenitas yang pertama kali dilakukan untuk bisa dilanjutkan ke Anova, karena syarat untuk ke uji Anova data harus normal dahulu. Dari hasil uji normalitas dengan menggunakan SPSS 15 didapatkan data berdistribusi normal. Dapat dilihat pada asymp.sign $\mathrm{R}_{1}, \mathrm{R}_{2}, \mathrm{R} 3$ dan $\mathrm{R}_{4}$ lebih besar dari nilai $\alpha(0,05)$.

Tabel 3. One-Sample Kolmogorov-Smirnov Test

\begin{tabular}{|l|l|r|r|r|r|}
\hline \multicolumn{2}{|c|}{} & \multicolumn{1}{|c|}{$\mathbf{R}_{\mathbf{1}}$} & \multicolumn{1}{|c|}{$\mathbf{R}_{\mathbf{2}}$} & \multicolumn{1}{c|}{$\mathbf{R}_{\mathbf{3}}$} & \multicolumn{1}{c|}{$\mathbf{R}_{\mathbf{4}}$} \\
\hline $\mathrm{N}$ & 9 & 9 & 9 & 9 \\
\hline \multirow{2}{*}{$\begin{array}{l}\text { Normal } \\
\text { Parameters(a,b) }\end{array}$} & Mean & 215.88890 & 222.11100 & 209.00000 & 208.11111 \\
\cline { 2 - 6 } $\begin{array}{l}\text { Most Extreme } \\
\text { Differences }\end{array}$ & Std Deviation & 56.07237 & 45.64385 & 55.89499 & 51.51321 \\
\cline { 2 - 6 } & Positive & .30000 & .26800 & .29200 & .32400 \\
\cline { 2 - 6 } & Negative & -.30000 & -.26800 & -.29200 & .324300 \\
\hline \multicolumn{2}{|l|}{ Kolmogorov-Smirnov Z } & .90000 & .80400 & .87600 & .97200 \\
\hline \multicolumn{2}{|l|}{ Asymp. Sig. (2-tailed) } & .39300 & .53700 & .42600 & .30100 \\
\hline
\end{tabular}

a Test distribution is Normal

b Calculated from data

2. Untuk uji homogenitas dengan menggunakan uji bartleet test, dengan perhitngan manual menggunakan Microsoft excel. Karena $\chi^{2}{ }_{\text {hitung }} 0,8998 \leq \chi^{2}$ tabel 5,991 sehingga dapat disimpulkan data yang ada termasuk homogen.

3. Pengolahan data dilakukan dengan menggunakan ANOVA terhadap rataan (mean) dan SN Ratio. Dengan melakukan strategi pooling up untuk mengoptimalkan faktor/interaksi antar faktor dengan syarat apabila Mq faktor lebih kecil daripada $\mathrm{Mq}_{\text {error }}$ dan bila $\mathrm{F}_{\text {hitung }}$ lebih kecil daripada $\mathrm{F}_{\text {tabel }}$.

a. Mean dan Pooling Up Mean

Tabel 4. Ringkasan Perhitungan Mean

\begin{tabular}{|c|c|c|r|r|r|r|}
\hline Source & S & v & Ms & F-ratio & S' & rho\% \\
\hline A & 31,76182 & 2 & 3663,7002 & 4,7468 & 5783,7494 & 6,48 \\
\hline B & 6,09531 & 2 & 7630,5095 & 9,8863 & 13717,368 & 15,38 \\
\hline C & 3,76198 & 2 & 22115,2606 & 28,6532 & 42686,8701 & 47,86 \\
\hline Error & 22382,9395 & 29 & 771,8255 & 1 & 27013,8925 & 30,28 \\
\hline St & 89201,88 & 35 & 2548,6251 & & 89201,88 & 100 \\
\hline Mean & 1645234,12 & 1 & & & & \\
\hline ST & 1734436 & 36 & & & & \\
\hline
\end{tabular}

Tabel 4 merupakan perhitungan mean, didapatkan bahwa Ms yang faktornya lebih kecil dari $\mathrm{Ms}_{\text {error }}$, tidak ada. Hal lain yang harus diperhatikan adalah nilai $\mathrm{F}$ hitung dangan nilai $\mathrm{F}$ tabel. Jika nilai $\mathrm{F}$ hitung faktor lebih kecil dari nilai $\mathrm{F}$ tabel, maka faktor tersebut harus di pooling up. Hal tersebut dilakukan karena faktor tersebut tidak berpengaruh secara signifikan sehingga digabungkan dengan nilai error. Hasil perhitungan mean menunjukkan bahwa nilai $\mathrm{F}$ hitung tidak ada yang lebil kecil dari $\mathrm{F}$ tabel. Dimana nilai $\mathrm{F}$ tabel untuk tingkat kepercayaan 95\% dengan derajat kebebasan 2 adalah $\mathrm{F}_{0,05 ; 2 ; 29}=3,33$ 
b. SN Ratio dan Pooling Up SN Ratio

Tabel 5. Ringkasan Perhitungan $S N$ ratio

\begin{tabular}{|c|c|c|c|c|}
\hline Source & SNR & v & MS SNR & F-ratio \\
\hline A & 189,5529 & 2 & 94,77645 & 27,381 \\
\hline B & 16,3073 & 2 & 8,15365 & 2,3556 \\
\hline C & 61,4718 & 2 & 30,7359 & 8,8796 \\
\hline Error & 100,3795 & 29 & 3,4616 & 1 \\
\hline St & 367,7115 & 35 & 10,506 & \\
\hline Mean & 5217,4907 & 1 & & \\
\hline ST & 5585,2022 & 36 & & \\
\hline
\end{tabular}

Tabel 6. Pooling Up SN Ratio Iterasi 1

\begin{tabular}{|c|c|c|c|c|c|}
\hline Source & Pool & SNR & v & MS SNR & F-ratio \\
\hline A & & 189,5529 & 2 & 94,77645 & 25,1791 \\
\hline B & Y & 16,3073 & 2 & - & - \\
\hline C & & 61,4718 & 2 & 30,7359 & 8,1655 \\
\hline Error & Y & 100,3795 & 29 & - & - \\
\hline Pooled & & 116,6868 & 31 & 3,7641 & \\
\hline St & & 367,7115 & 35 & 10,506 & \\
\hline Mean & & 5217,4907 & 1 & & \\
\hline ST & & 5585,2022 & 36 & & \\
\hline
\end{tabular}

Pada proses pooling up SN Ratio ini, proses pooling dilakukan hanya satu kali dan untuk sumber yang memiliki nilai Fhitung lebih kecil dari $\mathrm{F}_{\text {tabel. }}$.

Tabel 7. Hasil Akhir Perhitungan Pooling up SN Ratio

\begin{tabular}{|c|c|c|c|c|}
\hline Source & SNR & v & MS SNR & F-ratio \\
\hline A & 189,5529 & 2 & 94,77645 & 25,1791 \\
\hline C & 61,4718 & 2 & 30,7359 & 8,1655 \\
\hline Pooled & 116,6868 & 31 & 3,7641 & - \\
\hline St & 367,7115 & 35 & 10,506 & - \\
\hline Mean & 5217,4907 & 1 & - & - \\
\hline ST & 5585,2022 & 36 & - & - \\
\hline
\end{tabular}

4. Pemilihan setting level terbaik

Tabel 8. Pemilihan Setting Level Setiap Faktor yang Mempengaruhi Mean

\begin{tabular}{|c|c|c|c|}
\hline Faktor & A & B & C \\
\hline 1 & 233,1667 & 241,8333 & 164,25 \\
\hline 2 & 199,25 & 206,5 & 240,3333 \\
\hline 3 & 208,9167 & 193 & 236,75 \\
\hline
\end{tabular}


Tabel 9. Pemilihan Setting Level Setiap Faktor yang Mempengaruhi SN Ratio

\begin{tabular}{|c|c|c|}
\hline Parameter/level & A & C \\
\hline 1 & 23,1328 & 20,437 \\
\hline 2 & 18,9894 & 26,4484 \\
\hline 3 & 30,1102 & 25,3469 \\
\hline \multicolumn{2}{|c|}{ dipilih } \\
\hline
\end{tabular}

5. Untuk menentukan setting parameter optimum, maka dilanjutkan ke analisis Responce Surface Method.

a. Regressi Orde 1

Berikut model regresi orde 1 yang sesuai (perhitungan menggunakan software Minitab 13)

$$
\mathrm{Y}=214-12,1 \mathrm{~A}-24,4 \mathrm{~B}+36,3 \mathrm{C}
$$

\section{b. Regressi Orde 2}

Pembentukan model regresi Orde 2 dilakukan untuk mengoptimalkan respon dan setting parameter yang optimum dengan hasil sebagai berikut:

$$
\begin{aligned}
Y_{\text {fit }}= & 214-12.1 X_{1}-24.4 X_{2}+36.3 X_{3}-12.1 X_{1}^{2}-24.4 X_{2}^{2}+36.3 X_{3}^{2} \\
& +295,24 X_{1} X_{2}-439,23 X_{1} X_{3}-885,75 X_{2} X_{3}
\end{aligned}
$$

Nilai $\mathrm{x}_{1}, \mathrm{x}_{2}$, dan $\mathrm{x}_{3}$ dicari dengan rumus : $\mathrm{X}_{\mathrm{s}}=-0,5 \mathrm{x} \mathrm{B}^{-1} \mathrm{x} b$, dapat dicari dengan menggunakan persamaan matrik, sehingga didapat nilai $\mathrm{x}_{1}=-0,1181, \mathrm{x}_{2}=-0,0230$, dan $\mathrm{x}_{3}=0,0158$. Dengan demikian, nilai-nilai tersebut dimasukkan ke dalam model orde 2 dan didapatkan $\mathrm{Y}_{\mathrm{fit}}=216,3234$.

\section{Kesimpulan}

Dari pembahasan dapat ditarik beberapa kesimpulan sebagai berikut:

1. Faktor-faktor yang dianggap mempengaruhi kualitas hasil produksi produk roll 6"TL, adalah lama pembuatan cairan logam, kadar air pada campuran, lama waktu penuangan, lama pendinginan, total waktu penuangan, suhu cairan, ketebalan kucu, dan ketebalan cetakan. Faktor-faktor yang dianggap paling mempengaruhi kualitas hasil produksi produk roll 6"TL adalah:

a. Lama pembuatan cairan logam (faktor A)

b. Lama penuangan (faktor B)

c. Total waktu penuangan (faktor $\mathrm{C}$ )

2. Kombinasi setting level yang optimal berdasarkan hasil penelitian adalah:

a. Kombinasi setting level yang mempengaruhi mean (rata-rata) kualitas hasil produksi produk roll 6"TL pada faktor lama pembuatan cairan logam adalah pada level 100 menit, faktor lama penuangan adalah pada level 5 detik, faktor total waktu penuangan adalah pada level 14 menit..

b. Kombinasi setting level yang mempengaruhi varian kualitas (SN Ratio) hasil produksi roll 6"TL:

1) Faktor A, lama pembuatan cairan logam pada level 2 dengan setting waktu 100 menit. 
2) Faktor $\mathrm{C}$, total waktu penuangan pada level 1 dengan setting waktu 14 menit.

c. Kombinasi setting level dengan analisis Responce Surface Method (RSM), ada pada perlakuan kedua yaitu lama pembuatan cairan logam pada 90 menit, lama penuangan pada 4 detik, dan total waktu penuangan pada 16 menit.

d. Kualitas hasil pengecoran paling optimal ketika setting parameter berada di faktor A (lama pembuatan cairan logam) diset pada level 2 (100 menit), faktor B (lama penuangan) diset pada level 3 (5 detik), dan faktor C (total waktu penuangan) diset pada level 1 (14 menit).

\section{DAFTAR PUSTAKA}

1. Barnes, J. W., Statistical Analysis For Engineers and Scientists A Computer-Based Approach, International Edition, 1994.

2. Belavendram, N., Quality By Design: Taguchi Techniques for Industrial Experimentation, Prentice Hall, London, 1995.

3. Besterfield, D. H., Quality Control Sixth Edition, Upper Saddle River, New Jersey, Colombus Ohio, 2001.

4. Feigenbaum, A., V., Total Quality Control Third Edition Revised Fortieth Aniversary Edition, Mc Graw-Hill International Edition, Industrial Engineering Series, 1991.

5. Iriawan, N., Mengolah Data Statistik dengan Mudah Menggunakan Minitab 14, ANDI OFFSET, Yogyakarta, 2006.

6. Krismoyo, Y., Analisis Setting Parameter yang Optimum untuk Mendapatkan Jumlah Cacat Minimum pada Kualitas Roll 6”TL, Tugas Akhir Prodi Teknik Industri, FTI UAJY, 2010.

7. Mitra, A., Fundamentals of Quality Control and Improvement, MacMillan Publishing Co., New York, 1993.

8. Montgomery, D.C., Design and Analysis of Experiments, John Wiley \& Sons, New York, 1997.

9. Trihendradi, C., Step by Step SPSS 16 Analisis Data Statistik, ANDI OFFSET, Yogyakarta, 2009. 